\title{
Kualitas Produk, Pelayanan dan Nilai Syariah terhadap Persepsi Mahasiswa Ekonomi Islam untuk Menjadi Nasabah Bank Syariah
}

\author{
Dian Azmi Dinaratu \& Azhar Muttaqin \\ Program Studi Ekonomi Syariah, Fakultas Agama Islam, \\ Universitas Muhammadiyah Malang \\ E-mail: dianazmi26@gmail.com
}

\begin{abstract}
This study aims to determine how much influence the perception of Islamic economics students about product quality, service quality, and sharia value of interest to become customers of Islamic Bank. The result of data processing shows that the perception of product quality and service quality perception have positive and significant effect on the interest to become the customer of Islamic Bank proven with probability value (sig.) Of $0.000<0,05$. While the variable of perception of syariah value have positive and insignificant effect on interest to become customer of Islamic bank with result of probability value (sig.) Equal to $0,888>0,05$. Variable perception of product quality has the greatest and significant influence to the interest of becoming a customer of Islamic Bank indicated by $\mathrm{t}$ value counted 5,042. The perception of product quality, service quality, and sharia value influence $50,7 \%$ to interest to become customer of Islamic Bank in view from Adjusted R Square value and $49,3 \%(100 \%-50,7 \%)$ influenced by other variable outside variable The selected.
\end{abstract}

Keywords: Service Quality, Product Quality, and Student Perception.

\section{Pendahuluan}

Pertumbuhan dan perkembangan perbankan syariah masih jauh tertinggal jika dibandingkan dengan perkembangan bank konvensioanal. Upaya pengembangan bank syariah tidak cukup hanya berlandaskan kepada peraturan perundangundangan dan aspek legal lain, tetapi juga harus lebih berorientasi kepada pasar yaitu masyarakat sebagai pengguna jasa (konsumen atau nasabah) bank syariah itu sendiri. Perbankan syariah yang berorientasi kepada pasar harus memperhatikan aspek-aspek penting dalam operasional perbankan itu sendiri, yaitu kualitas produk, kualitas pelayanan, serta keistimewaan bank syariah dibandingkan dengan 
bank konvensional yaitu nilai syariah. Namun, permasalahan dikalangan masyarakat yang masih minim pemahaman mengenai perbankan syariah tentunya dapat menimbulkan peresepsi negatif yang akan menurunkan minat menggunakan jasa perbankan syariah. Jika pemahaman dikalangan masyarakat sangat minim bagaimana dengan pemahaman dikalangan mahasiswa. Dari salah satu riset yang dilakukan Departemen Riset SEF UGM menemukan ternyata pemahaman mahasiswa tentang bank syariah terutama dasar ekonomi Islam seperti misalnya fiqih muamalah dan hakikat riba, hasilnya pengetahuan mahasiswa masih sangat rendah. Hampir semua responden yaitu sekitar 95\% mahasiswa telah mengetahui adanya bank syariah, namun hanya $27 \%$ responden yang mengetahui tentang produk-produk bank syariah. Kepemilikian rekening di bank syariah juga rendah dilihat dari riset yang dilakukan oleh Departemen Riset SEF UGM dengan mensurvey sebanyak 172 responden hanya sebanyak $16,67 \%$ responden yang memiliki rekening bank syariah dan $72,6 \%$ responden masih belum memliki rekening di bank. ${ }^{1}$

Riset yang dilakukan oleh MARS Indonesia per akhir tahun 2011 mengenai kepemilikan rekening di bank syariah berdasarkan usianya di 5 kota besar yaitu Jakarta, Bandung, Surabaya, Semarang dan Medan menemukan bahwa persentase terbesar nasabah perbankan syariah ada pada kelompok usia tua (35-55 tahun), yaitu mencapai 50,8\%. Berikutnya ada pada kelompok dewasa (25-34 tahun) sebesar 37,6\%, dan pada kelompok usia muda (18-24 tahun) hanya 11,6\%. Padahal pada usia 18-24 tahun merupakan usia ideal mahasiswa yang sedang menempuh jenjang Stara 1. Dari riset di atas dapat diketahui bahwa dukungan mahasiswa dengan menjadi nasabah bank syariah masih sangat rendah. ${ }^{2}$ Lalu bagaimana dengan mahasiswa Ekonomi Islam atau Ekonomi Syariah apakah hal tersebut berlaku sama pada mahasiswa Ekonomi Islam atau Ekonomi Syariah. Jika pemahaman menjadi salah satu faktor yang meningkatkan peluang adopsi, tentunya peran akademisi khususnya mahasiswa ekonomi Islam sangat di butuhkan dalam perkembangan bank syariah. Terlebih lagi mahasiswa ekonomi Islam memiliki pengetahuan lebih mengenai perbankan syariah yang diperoleh dari bangku perkuliahan. Dengan demikian mahasiswa ekonomi Islam di dalam masyarakat memainkan peran penting dalam penentuan minat masyarakat untuk memilih penggunaan bank Islam, membentuk dan menanamkan kesadaran yang tinggi bahwa tata kembang ekonomi atau investasi melalui sistem lembaga keuangan Islam dapat bermanfaat bagi banyak orang. Mahasiswa ekonomi Islam dapat melakukan pendekatan interpersonal dan pendekatan individu kepada masayarakat, pendekatan tersebut lebih memainkan peran penting dalam menarik

\footnotetext{
1 Departemen Riset SEF UGM, Pengetahuan Ekonomi Islam di Kalangan Mahasiswa dan Preferensi Terhadap Bank Syariah di Indonesia, diakses pada tanggal 20 Maret 2017 dari http://www.kompasiana.com/abdulkarimismail/bank-idolaku-tumbuh-dan-berkembanglah-dikancah-dunia-kapitalis 54ff2bc1a33311b34550fc86,

${ }^{2}$ Mars Indonesia, Kepemilikan Rekening di Bank Syariah, diakses pada tanggal 20 maret 2017 dari www.marsindonesia.com/newsletter/kepemilikan-rekening-di-bank-syariah-meningkat.
} 
masyarakat dalam menggunakan jasa bank syariah. Berdasarkan latar belakang di atas, terdapat permasalahan yang diangkat dalam penelitian ini. Bagaimana pengaruh persepsi mahasiswa Ekonomi Islam tentang kualitas produk, kualitas pelayanan, dan nilai syariah terhadap minat menjadi nasabah di Bank Syariah? Penelitian ini memiliki tujuan, mengetahui seberapa besar pengaruh persepsi mahasiswa Ekonomi Islam tentang kualitas produk, kualitas pelayanan dan nilai syariah terhadap minat menjadi nasabah di bank syariah.

\section{Bank Syariah: Prinsip Dasar, dan Nilai-Nilainya}

Bank Islam atau yang biasa disebut dengan Bank Syariah merupakan bank yang beroperasi dengan tidak mengandalkan pada bunga. Bank Islam atau Bank Tanpa Bunga ialah lembaga keuangan atau perbankan yang operasional dan produknya dikembangkan berdasarkan pada Al-Qur'an dan Hadist Nabi SAW. Atau dengan kata lain Bank Syariah adalah lembaga keuangan yang usaha pokoknya memberikan pembiayaan dan jasa-jasa lainnya dalam lalu lintas pembayaran serta peredaran uang yang pengoperasiannya disesuaikan dengan prisnsip Islam. ${ }^{3}$ Syafi'i Antonio dan Perwataatmadja membedakan Bank Syariah menjadi dua pengertian, yaitu Bank Islam dan Bank yang beroperasi dengan prinsip syariah Islam. Bank Islam adalah (1) bank yang beroperasi sesuai dengan prinsip-prinsip syariah Islam; (2) bank yang tata cara beroperasinya mengacu kepada ketentuan-ketentuan Al-Qur'an dan Hadist. Sedangakan bank yang beroperasi sesuai dengan prinsip syariah Islam adalah bank yang dalam beroperasinya mengikuti ketentuan-ketentuan syariah Islam, khususnya yang menyangkut tata cara bermuamalat secara Islam. Tata cara tersebut merupakan tata cara dalam bermuamalat dengan menjauhi praktek-praktek yang dikhawatirkan mengandung unsur-unsur riba dang mengubahnya dengan kegiatan-kegiatan investasi atas dasar bagi hasil dan pembiayaan perdagangan. ${ }^{4}$

Pada dasarnya prinsip-prinsip perbankan syariah adalah sebagai berikut: ${ }^{5}$

1) Prinsip At Ta'awun, yaitu saling membantu dan saling bekerja sama diantara anggota masyarakat untuk kebaikan, sebagaimana dinyatakan dalam Al-Qur'an: ${ }^{6}$

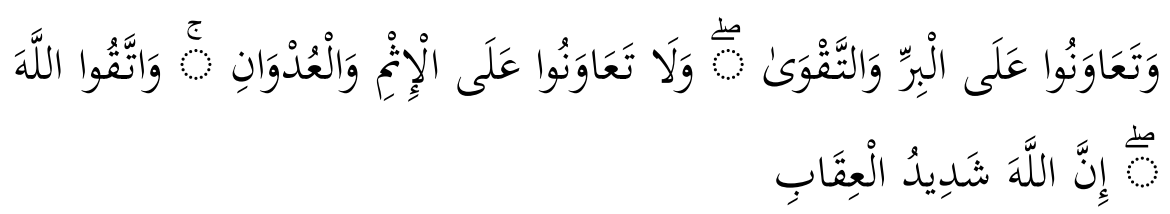

\footnotetext{
${ }^{3}$ Muhammad, Manajemen Bank Syari'ah, (Yogyakarta: UPP AMP YKPWN, 2002), 13.

4 Karnaen Perwataatmadja, M. Syafe'i Antonio, Apa dan Bagaimana Bank Islam, (Yogyakarta: PT. Dana Bakti Wakaf, 1997), 1

${ }^{5}$ Zainul Arifin, Dasar-dasar Manajemen Bank Syari'ah, (Jakarat: Azakia Publisher, 2009), 15.

${ }^{6}$ QS. Al-Maidah [5]: 2.
} 
“.....Dan tolong-menolonglah kamu dalam (mengerjakan) kebajikan dan taqwa, dan jangan tolong -menolong dalam berbuat dosa dan pelanggaran..." (QS. Al-Maidah:2)

2) Prinsip menghindari Al Iktinaz, yaitu menahan uang (dana) dan membiarkannya menganggur (idle) dan tidak berputar dalam transaksi yang bermanfaat bagi masyarakat umum, sebagaimana dinyatakan di dalam Al-Qur'an: ${ }^{7}$

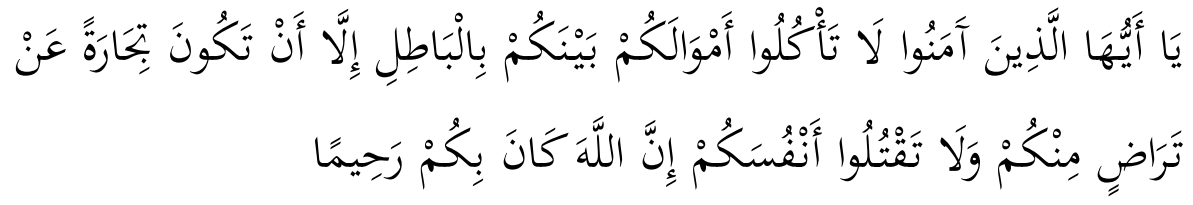

"hai orang-orang yang beriman, janganlah kamu saling memakan harta sesamamu dengan jalan batil, kecuali dengan jalan perniagaan yang berlaku dengan suka sama suka dianatara kamu..." (QS. AnNisa'[4]: 29)

Perbedaan pokok antara perbankan Syariah denganperbankan konvensional (bunga) adalah adanya prinsip bungadalam perbankan konvensional. Dalam Islam, melarang ribadan menghalalkan jualbeli. Prinsip utama yang dianut olehBank Islam adalah : ${ }^{8}$ pertama, larangan riba (bunga) dalam berbagai bentuk transaksi. Kedua, menjalankan bisnis dan aktivitas perdagangan yang berbasis pada perolehan keuntungan yang sah menurut syariah; dan memberi zakat.

\section{Kualitas Produk, Jasa dan Nilai Syariah}

Kualitas produk dan jasa perbankan dapat mempengaruhi persepsi dan kepuasan nasabah melalui ketepatan waktu pelayanan penyampaian, ketersediaan produk dan layanan saat dibutuhkan, kebenaran janji promosi atas produk dan layanan, kesesuaian pesanan, keamanan dan keselamatan, fleksibilitas pembayaran, ketersediaan fasilitas pelayanan dan kemudahan pengambilan, termasuk biaya administrasi dan pemeliharaannya, serta kemampua penyempurnaan produk layanan secara terus-menerus tanpa batas. Kualitas itu bertitik tolak dari proses bukan hasiil, quality comes from the improvement of the proccess and no outcome. Oleh karenanya keterlibatan manusia-semua orang mitra internal bank sangat diperlukan dalam mengikuti tuntutan nasabah yang semakin lama semakin meningkat dan termasuk melihat dan mengungguli perkembangan kualitas jasa layanan yang dihasilkan para pesaing lainnya. ${ }^{9}$ Penilaian nasabah terhadap jasa perbankan berkaitan dengan tingkat subjektivitas,

${ }^{7}$ QS. An-Nisa [4]:29.

${ }^{8}$ Ibid., Zainul Arifin, Dasar-dasar Manajemen Bank Syari'ah.., 15.

${ }^{9}$ Ibid., Zainul Arifin, Dasar-dasar Manajemen Bank Syari'ah.., 88-89. 
aspirasi emosi, kepuasan, keengganan, suasana hati, dan pengalamannya. Ada beberapa proses dalam pengembangan operasional bank pada kualitass layanan jasa perbankan yang baik, meliputi: ${ }^{10}$ akses, komunikasi, sikap membantu nasabah, kompetensi, sopan santun, kehandalan produk, keamanan, wujud fisik, tingkat pemahaman akan keinginan nasabah, citra, persepsi nasabah tentang tingkat keterlibatannya dalam mempengaruhi jasa yang diterimanya.

Didalam Al-Qur'an juga dijelaskan bagaimana produk jasa yang baik yaitu dalam firman Allah swt: ${ }^{11}$

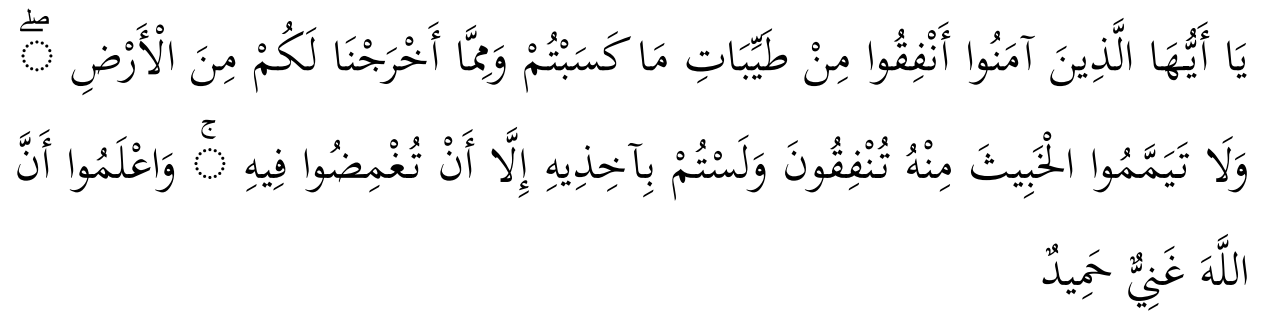

" Hai orang-orang yang beriman, nafkahkanlah (di jalan Allah) sebagian dari hasil usahamu yang baik-baik dan sebagian dari apa yang Kami keluarkan dari bumi untuk kamu. Dan janganlah kamu memilih yang buruk-buruk lalu kamu menafkahkan daripadanya, padahal kamu sendiri tidak mau mengambilnya melainkan dengan memincingkan mata terhadapnya. Dan ketahuilah, bahwa Allah Maha Kaya Lagi Maha Terpuji.” (QS. Al-Baqarah[2]: 267)

Islam mengajarkan bila ingin memberikan hasil usaha yang baik berupa produk jasa hendaknya memberikan yang berkualitas, dan jangan memberikan yang buruk atau tidak berkualitas kepada orang lain. Sehinga kualitas produk jasa sangat dianjurkan dalam Islam, kualitas produk jasa yang baik dapat meningkatkan loyalitas konsumen pengguna produk jasa itu sendiri dan nantinya akan mendatangkan keuntungan bagi perusahan (bank syariah) yang menerapkan hal tersebut.

Selanjutnya, kualitas pelayanan sebagai kemampuan merencanakan, menciptakan, dan menyerahkan produk yang bermanfaat luar biasa bagi nasabah. Kualitas pelayanan yang dirasakan nasabah merupakan penilaian global, berhubungan dengan suatu transaksi spesifik, lebih abstraks dan ekslusif karena didasarkan pada persepsi-persepsi kualitas yang berhubungan dengan kepuasan serta komparasi harapan-harapan dengan persepsi-persepsi kinerja produk jasa bank, fleksibilitas respons terhadap perubahan permintaan pasar. Kualitas pelayanan merupakan ciri dan sifat dari pelayanan yang berpengaruh kepada kemampuan karyawan untuk memuaskan kebutuhan yang dinyatakan oleh pelanggan atau yang tersirat dalam diri pelanggan. Kualitas jasa bank melekat

${ }^{10}$ Ibid, Zainul Arifin, Dasar-dasar Manajemen Bank Syari'ah.., 88-89.

${ }^{11}$ QS. Al-Baqarah [2]: 267. 
pada karyawan dalam meberikan pelayanan jasa kepada nasabah, kualitas karywan merupakan merupakan salah satu faktor diferensiasi antara bank yang satu dengan bank lainnya, sekaligus sebagai salah satu rantai nilai yang dapat mencipatakan competitive advantage bagi bank yang bersangkutan. Sejumlah karakteristik kualitas karyawan terdiri atas berikut: ${ }^{12}$ kompetensi, sopan santun, kredibilitas, kehandalan, ketanggapan, renpons, kemampuan menanggapi keluhan nasabah, tepat waktu, komunikasi.

Di dalam Islam dijelaskan bagaimana kualitas pelayanan menurut Al-Qur'an, sebagaimana firman Allah SWT.: ${ }^{13}$

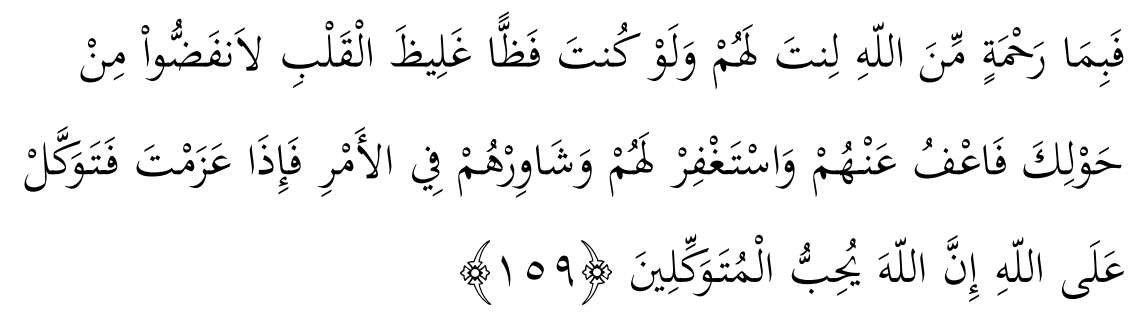

"Maka disebabkan rahmat dari Allah-lah kamu berlaku lemahlembut terhadap mereka. Sekiranya kamu bersikap keras lagi berhati kasar, tentulah mereka menjauhkan diri dari sekelilingmu. Karena itu maafkanlah mereka, mohonkanlah ampun bagi mereka, dan bermusyawarahlah dengan mereka dalam urusan itu. Kemudian apabila kamu telah membulatkan tekad, maka bertawakallah kepada Allah. Sesungguhnya Allah menyukai orangorang yang bertawakal kepada-Nya." (QS. Ali-Imran: 159)

Baik buruknya pelayanan yang diberikan akan menentukan keberhasilan lembaga atau perusahaan pemberi jasa pelayanan. Dengan memberikan pelayanan yang berkualitas menjadikan rasa kenyamanan bagi konsumen dan menimbulkan loyalitas konsumen dan dampaknya kembali lagi pada perusahaan atau lembaga penyedia jasa pelayanan.

Salah satu bentuk penggalian potensi masyarakat dalam perekonomian nasional adalah pengembangan sistem ekonomi berdasarkan nilai-nilai (prinsip syariah). Prinsip syariah berlandaskan pada nilai-nilai keadilan, kemanfaatan, keseimbangan, dan keuniversalan (rahmatan lil 'alamin). Nilai-nilai tersebut diterapkan dalam peraturan perbankan berdasarkan prinsip syariah yang disebut dengan perbankan syariah. Perbankan syariah merupakan bagian dari prinsip ekonomi Islam antara lain adalah larangan riba dalam berbagai bentuk yang

\footnotetext{
${ }^{12}$ Ibid. Zainul Arifin, Dasar-dasar Manajemen Bank Syari'ah.., 91-92.

${ }^{13}$ QS. Ali-Imran [3]:159.
} 
diganti dengan prinsip bagi hasil. ${ }^{14}$ Hal tersebut juga dijelaskan dalam Al-Qur'an sebagaimana firman Allah SWT: ${ }^{15}$

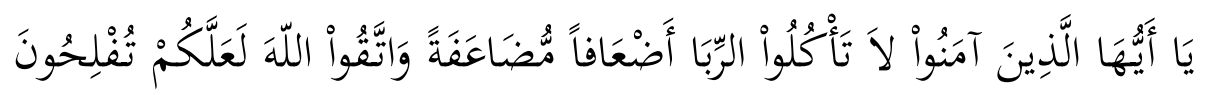

"Hai orang-orang yang beriman, janganlah kamu memakan riba dengan berlipat ganda dan bertaqwalah kamu kepada Allah supaya kamu mendapatkan keberuntungan." (QS. Ali-Imran: 130)

Dengan menggunakan prinsip tersebut bank syariah dapat menciptakan iklim investasi yang sehat dan adil, karena semua pihak dapat saling berbagi keuntungan maupun kerugian yang timbul, sehingga tercipta posisi yang berimbang antara bank dan nasabahnya. Prinsip syariah adalah ketentuan hukum Islam yang menjadi pedoman dalam kegiatan operasional perusahaan dan transaksi antara lembaga keuangan atau lembaga bisnis syariah dengan pihak lain yang telah dan akan diatur oleh Dewan Syariah Nasional. Kegiatan bisnis berbasis syariah tidak boleh bertentangan dengan prinsip-prinsip syariah, dengan kata lain kegiatan bisnis tersebut tidak boleh berbentuk: ${ }^{16}$ perjudian (maysir), ketidakpastian (gharar), haram, riba. Guna menjamin produk jasa serta operasional bank syariah terjamin kehalalannya maka adanya Dewan Pengawa Syariah (DPS) memberikan kenyamanan kepada nasabah mengenai kehalalan produk jasa bank syariah. Dewan Pengawa Syariah (DPS) adalah dewan yang keanggotaannya direkomendasikan oleh Dewan Syariah Niasional dan ditempatkan pada bank yang melakukan kegiatan usaha berdasarkan prinsip syariah, dengan tugas dan kewenangan yang diatur oleh Dewan Syariah Nasional. DPS melakukan pengawasan terhadap penerapan prinsip syariah dalam lembaga keuangan syariah. ${ }^{17}$

\section{Kualitas Produk, Jasa dan Nilai Syariah dan Relevansinya terhadap Persepsi Mahasiswa Ekonomi Islam untuk Menjadi Nasabah Bank Syariah}

Penelitian ini menggunakan pendekatan kuantitatif dengan jenis penelitian deskriptif kuantitatif. Metode pengumpulan data dalam penelitian ini adalah metode survey. Sampel yang digunakan dalam penelitian ini merupakan mahasiswa program studi ekonomi Islam di Universitas Muhammadiyah Malang

\footnotetext{
${ }^{14}$ Iswi Hariyani, R. Serfianto, dan Citra Yustisia, Marger, konsolidasi, Akuisisi, \& Pemisahan Perusahaan: Cara Cerdas Mengembangkan \& Memajukan Perusahaan, (Jakarta: Visimedia, 2011), 197.

${ }^{15}$ QS. Ali-Imran [3]: 130.

16 Ibid. Iswi Hariyani, R. Serfianto, dan Citra Yustisia, Marger, konsolidasi, Akuisisi, \& Pemisahan.., 198-199.

${ }^{17}$ Ahmad Ifham Sholihin, Buku Pintar Ekonomi Syariah, (Jakarta: PT Gramedia Pustaka Utama, 2010), 240.
} 
dan Universitas Brawijaya angkatan 2013, 2014, 2015. Dalam penelitian ini jumlah sampel yang diambil sebanyak 114 responden yang dipilih menggunakan teknik non probability sampling dengan sampling kuota. Pengumpulan data menggunakan kuisioner sehingga data yang digunakan dalam penelitian ini merupakan data primer dari hasil jawaban kuesionnaire. Pembahasan hasil penelitian ini akan mendeskripsikan hasil penelitian dari data yang telah dikumpulkan berupa angket atau kuisioner untuk menjawab permasalahan yang telah dibahas pada bab sebelumnya yaitu bagaimana pengaruh persepsi mahasiswa ekonomi Islam tentang kualitas produk, kualitas pelayananan dan nilai syariah terhadap minat menjadi nasabah bank syariah. Penjelasan dari hasil penelitian ini di uraikan sebagai berikut:

1) Analisis Regresi Linier Berganda

Pengujian ini digunakan software SPSS 21, hasil uji regresi liner berganda dapat dilihat pada tabel di bawah ini:

Tabel 1. Hasil Uji Analisis Regresi Linier Berganda

Coefficients $^{a}$

\begin{tabular}{|c|c|c|c|c|c|c|c|}
\hline \multirow[t]{2}{*}{ Model } & \multicolumn{2}{|c|}{$\begin{array}{l}\text { Unstandardized } \\
\text { Coefficients }\end{array}$} & $\begin{array}{l}\text { Standardized } \\
\text { Coefficients }\end{array}$ & \multirow[t]{2}{*}{$\mathrm{T}$} & \multirow[t]{2}{*}{ Sig. } & \multicolumn{2}{|c|}{$\begin{array}{l}\text { Collinearity } \\
\text { Statistics }\end{array}$} \\
\hline & B & Std. Error & Beta & & & Tolerance & VIF \\
\hline (Constant) & 7,234 & 1,685 & & 4,294 & , 000 & & \\
\hline $\begin{array}{l}\text { Persepsi Kualitas } \\
\text { Produk }\end{array}$ & 412 & ,082 & 462, & 5,042 & ,000 & ,519 & $\begin{array}{r}1,92 \\
8\end{array}$ \\
\hline $\begin{array}{l}{ }^{1} \text { Persepsi Kualitas } \\
\text { Pelayanan }\end{array}$ & 279 & ,072 & 333 & 3,860 & , 000 & ,585 & $\begin{array}{r}1,70 \\
8\end{array}$ \\
\hline $\begin{array}{l}\text { Persepsi Nilai } \\
\text { syari'ah }\end{array}$ & ,012 & ,083 & , 013 & 141 & ,888 & ,539 & $\begin{array}{r}1,85 \\
4\end{array}$ \\
\hline
\end{tabular}

a. Dependent Variable: Minat menjadi Nasabah Bank Syariah

(Sumber: Data Primer yang diolah, 2017)

Berdasarkan tabel 1. di atas, pada kolom B tercantum nilai konstanta dan nilai-nilai koefisien regresi linier berganda untuk masing-masing variabel bebas. Berdasar nilai-nilai itu maka dapat ditentukan model regresi linier berganda yang dinyatakan dalam bentuk persamaan sebagai berikut:

$$
Y=7,234+0,412 X_{1}+0,279 X_{2}+0,012 X_{3}
$$

Keterangan:

Y : Minat menjad nasabah Bank Syariah

$\mathrm{X}_{1}$ : Persepsi Kualitas Produk

$\mathrm{X}_{2}$ : Persepsi Kualitas Pelayanan

$\mathrm{X}_{3}$ : Persepsi Nilai Syariah 
Berdasarkan rumus regresi linier berganda di atas dapat dinyatakan nilai koefisiannya sebagai berikut:

a) Nilai konstanta sebesar 7,234, hasil ini menunjukkan apabila semua variable independen bernilai nol (0) maka nilainya akan sebesar 7,234.

b) Koefisien regresi variable persepsi kualitas produk $\left(\mathrm{X}_{1}\right)$ sebesar 0,412, artinya jika variable independen lainnya bernilai tetap dan persepsi kualitas produk $\left(\mathrm{X}_{1}\right)$ mengalami kenaikan sebesar $1 \%$, maka persepsi kualitas produk $\left(\mathrm{X}_{1}\right)$ akan mengalami kenaikan sebesar 0,412.

c) Koefisien regresi variable persepsi kualitas pelayanan $\left(\mathrm{X}_{2}\right)$ sebesar 0,279 , artinya jika variable independen lainnya bernilai tetap dan persepsi kualitas pelayanan $\left(\mathrm{X}_{2}\right)$ mengalami kenaikan sebesar $1 \%$, maka persepsi kualitas pelayanan $\left(\mathrm{X}_{2}\right)$ akan mengalami kenaikan sebesar 0,279.

d) Koefisien regresi variable persepsi nilai syariah $\left(\mathrm{X}_{3}\right)$ sebesar 0,012, artinya jika variable independen lainnya bernilai tetap dan persepsi nilai syariah $\left(\mathrm{X}_{3}\right)$ mengalami kenaikan sebesar $1 \%$, maka persepsi niali syariah $\left(\mathrm{X}_{3}\right)$ akan mengalami kenaikan sebesar 0,012.

2. Pengujian Hipotesis

a) Pengujian secara Parsial

Uji signifikansi terhadap masing-masing koefisien regresi diperlukan untuk mengetahui signifikan tidaknya masing-masing variabel bebas (X) terhadap variabel terikat (Y).Selain itu uji parsial dapat dilakukan dengan melihat dari probabilitas $\mathrm{t}$ statistik. Dimana $\mathrm{H}_{0}$ ditolak jika Probabilitas (tstatistics $<\alpha(0.05)$, begitu juga sebaliknnya dimana apabila $\mathrm{H}_{1}$ diterima jika Probabilitas (t-statistic $>\alpha(0.05)$. hasil uji t dapat dilihat pada tabel berikut:

Tabel 2. Hasil Uji t

Coefficients $^{\mathrm{a}}$

\begin{tabular}{|l|r|r|r|r|r|}
\hline Model & \multicolumn{2}{|c|}{$\begin{array}{c}\text { Unstandardized } \\
\text { Coefficients }\end{array}$} & \multicolumn{2}{c|}{$\begin{array}{c}\text { Standardized } \\
\text { Coefficients }\end{array}$} & \multicolumn{1}{c|}{ Sig. } \\
\cline { 2 - 4 } & \multicolumn{1}{|c|}{ B } & Std. Error & \multicolumn{2}{|c|}{ Beta } & \\
\hline (Constant) & 7,234 & 1,685 & & 4,294 &, 000 \\
Persepsi Kualitas Produk &, 412 &, 082 &, 462 & 5,042 &, 000 \\
1 Persepsi Kualitas &, 279 &, 072 &, 333 & 3,860 &, 000 \\
Pelayanan & & &, 013 &, 141 &, 888 \\
Persepsi Nilai syari'ah &, 012 &, 083 & & & \\
\hline
\end{tabular}

a. Dependent Variable: Minat menjadi Nasabah Bank Syariah

Catatan: Nilai $t_{\text {tabel }}$ pada $\alpha=0,05$; dengan df : $\mathrm{n}-(\mathrm{k}+1) ; 114-(3+1)=110($ angka terdekat 120) uji dua arah sebesar 1,980. 
Berdasarkan hasil uji-t pada tabel 2, pengaruh masing-masing variabel dapat dijelaskan sebagai berikut:

a) Pengaruh Persepsi Mahasiswa Ekonomi Islam Tentang Kualitas Produk Terhadap Minat Menjadi Nasabah Bank Syariah

Hasil uji data yang telah dilakukan dalam penelitian ini menunjukkan pengaruh persepsi tentang kualitas produk terhadap minat menjadi nasabah Bank Syariah memiliki pengaruh positif signifikan. Hal ini dapat dilihat dari hasil pengujian dengan menggunakan SPSS 21 yang menunjukkan nilai t pada variabel persepsi kualitas produk sebesar 5,042 (tanda positif). Niali signifikansi sebesar 0,000 yang nilainya lebih kecil dari pada $\alpha=$ $0,05(0,000<0,05)$. Hal ini menunjukkan bahwa adanya pengaruh yang positif signifikan persepsi kualitas produk terhadap minat menjadi nasabah Bank Syariah. Produk yang dipersepsikan memiliki kualitas adalah produk yang memiliki kesesuaian dengan yang dibutuhkan atau diinginkan oleh pelanggan (nasabah), dan secara konsisten dapat memenuhi kepuasan pelanggan tanpa cacat sedikitpun. ${ }^{18}$ Persepsi positif yang timbul tentang kualitas produk ini dapat berpengaruh terhadap minat menjadi nasabah bank syariah.

Sedangkan menurut Rahayu Istiqomah dalam skripsinya tahun 2015, ${ }^{19}$ ditemukan bahwa kualitas produk berpengaruh positif signifikan terhadap keputusan menjadi nasabah di Bank Syariah, hal ini ditunjukkan dengan nilai signifikansi $<0,05$. Selanjutnya dari hasil penelitian yang dilakukan oleh penulis dalam penelitian ini diketahui bahwa kualitas produk perbengaruh secara positif signifikan terhadap minat menjadi nasabah Bank Syariah sebab memiliki niali signifikansi sebesar 0,000 yang nilainya lebih kecil dari pada $\alpha=0,05(0,000<0,05)$. Sehingga dalam penelitian ini mendukung dari hasil penelitian yang dilakukan oleh Rahayu Istiqomah.

b) Pengaruh Persepsi Mahasiswa Ekonomi Islam Tentang Kualitas Pelayanan Terhadap Minat Menjadi Nasabah Bank Syariah

Hasil uji data yang telah dilakukan dalam penelitian ini menunjukkan pengaruh persepsi tentang kualitas pelayanan terhadap minat menjadi nasabah Bank Syariah memiliki pengaruh positif signifikan. Hal ini dapat dilihat dari hasil pengujian dengan menggunakan SPSS 21 yang menunjukkan nilai t pada variabel persepsi kualitas pelayanan sebesar 3,860 (tanda positif). Niali signifikansi sebesar 0,000 yang nilainya lebih

\footnotetext{
18 Ali Hasan, Marketing Bank Syariah Cara Jitu Meningkatkan Pertumbuhan Pasar Bank Syariah, Cet. ke-1, (Bogor: PT Ghalia Indonesia, 2010), 72

${ }^{19}$ Rahayu Istiqomah, Faktor-Faktor Yang Mempengaruhi Keputusan Mahasiswa Perbankan Syariah STAIN SALATIGA Untuk Menjadi Nasabah DI Perbankan Syariah. Skripsi Perbankan Syariah, STAIN SALATIGA, Salatiga 2015, 96.
} 
kecil dari pada $\alpha=0,05$ koefisien ini signifikan pada $\alpha=0,05(0,000<$ 0,05). Hal ini menunjukkan bahwa adanya pengaruh yang positif signifikan persepsi kualitas pelayanan terhadap minat menjadi nasabah Bank Syariah. Kualitas pelayanan merupakan manfaat yang dirasakan berdasarkan evaluasi konsumen atas suatu interaksi dibandingkan dengan manfaat yang diharapakan sebelumnya. Persepsi terhadap kualitas pelayanan merupakan hasil perbandingan antara harapan pelanggan dengan kinerja aktual pelayanan. ${ }^{20}$ Jika kinerja aktual pelayanan melebihi ekspektasi yang diharapkan maka kualitas pelayanan akan menimbulkan persepsi positif yang nantinya berpengaruh terhadap loyalitas dan minat pelanggan.

Sedangkan menurut Rahayu Istiqomah dalam skripsinya tahun 2015,21 ditemukan bahwa kualitas pelayanan berpengaruh positif signifikan terhadap keputusan menjadi nasabah di Bank Syariah, hal ini ditunjukkan dengan nilai signifikansi $<0,05$. Selanjutnya dari hasil penelitian yang dilakukan oleh penulis dalam penelitian ini diketahui bahwa kualitas pelayanan perbengaruh secara positif signifikan terhadap minat menjadi nasabah Bank Syariah sebab memiliki niali signifikansi sebesar 0,003 yang nilainya lebih kecil dari pada $\alpha=0,05(0,003<0,05)$. Sehingga dalam penelitian ini mendukung dari hasil penelitian yang dilakukan oleh Rahayu Istiqomah.

c) Pengaruh Persepsi Mahasiswa Ekonomi Islam Nilai Syariah Terhadap Minat Menjadi Nasabah Bank Syariah

Nilai syariah adalah kesesuaian kinerja operasional perbankan syari'ah dengan syariat Islam yang sesuai dengan Al-Qur'an dan as-Sunnah. Hal tersebut tentunya dapat menimbulkan persepsi positif dikalangan masyarakat. Hasil uji data yang telah dilakukan dalam penelitian ini menunjukkan pengaruh persepsi tentang nilai syariah terhadap minat menjadi nasabah Bank Syariah memiliki pengaruh positif. Hal ini dapat dilihat dari hasil pengujian dengan menggunakan SPSS 21 yang menunjukkan nilai t pada variabel persepsi nilai syariah sebesar 0,141 (tanda positif). Niali signifikansi sebesar 0,888 yang nilainya lebih besar dari pada $\alpha=0,05(0,888>0,05)$. Hal ini menunjukkan bahwa adanya pengaruh yang positif tidak signifikan persepsi nilai syariah terhadap minat menjadi nasabah Bank Syariah.

20 Ardiansyah Sudarsono, Manajemen Pemasaran Jasa Perhotelan. Ed. 1. Cet. ke-1. Yogyakarta: Deepublish, 2016), 57.

21 Ibid, Rahayu Istiqomah, Faktor-Faktor Yang Mempengaruhi Keputusan Mahasiswa Perbankan.., 96. 
Sedangkan menurut Faisal dalam skripsinya tahun $2016,{ }^{22}$ ditemukan bahwa religiusitas tidak memilki pengaruh yang signifikan terhadap minat untuk menjadi nasabah bank syariah, hal ini ditunjukkan dengan nilai signifikansi > 0,05. Selanjutnya dari hasil penelitian yang dilakukan oleh penulis dalam penelitian ini sejalan dengan penelitian sebelumnya diketahui bahwa nilai syariah perbengaruh secara positif tidak signifikan terhadap minat menjadi nasabah Bank Syariah sebab memiliki niali signifikansi sebesar 0,502 yang nilainya lebih besar dari pada $\alpha=0,05$ $(0,502>0,05)$. Nilai syariah yang diterapkan pada bank syariah tentunya berbeda-beda sehingga dapat menimbulkan persepsi yang berbeda-beda pula. Didalam penelitian ini nilai syariah memilki pengaruh positif dan tidak signifikan terhadap minat menjadi nasabah bank syariah dikarenakan kebutuhan mahasiswa selama perkuliahan yaitu menerima transfer dari orang tua dan juga dikarenakan adanya tugas perkuliahan. Sesuai dari hasil wawancara sebagai berikut:

a) Wawancara dengan Ismi, mahasiswa Ekonomi Islam Universitas Brawijaya, "kalau angkatan saya dulu pernah ditanyakan oleh dosen yang menggunakan bank syariah dan ternyata hanya dua mahasiswa yang menggunakan bank syariah, lalu akhirnya satu kelas tersebut diberikan tugas untuk membuka rekening tabungan di bank syariah". ${ }^{23}$

b) Wawancara dengan Rohana, mahasiswa Ekonomi Syariah di Universitas Muhammadiyah malang "saya menggunakan bank syariah karena kebutuhan transaksi yaitu transfer bulanan dari orang tua. Karena orang tua saya juga menggunakan BNI Syariah jadi untuk mempermudah transfer saya juga membuka rekening tabungan di bank BNI Syariah juga". ${ }^{24}$ Sehingga tidak sepenuhnya mahasiswa ekonomi Islam yang menjadi nasabah bank syariah dikarenakan kesadaran penuh dari diri sendiri, mengingat dari hasil beberapa wawancara yang telah dilakukan.

\section{Pengujian Secara Simultan}

Uji F yang signifikan menunjukkan bahwa variasi variabel terikat dijelaskan sekian persen oleh variabel bebas secara bersama-sama adalah benar-benar nyata dan bukan terjadi karena kebetulan. Hasil uji F dapat dilihat pada tabel berikut ini:

\section{Tabel 3. hasil Uji F}

\footnotetext{
${ }^{22}$ Faisal, Faktor-faktor Yang Mempengaruhi Minat Mahasiswa Untuk Menjadi Nasabah di Bank Syariah: Studi Kasus Mahasiswa Ekonomi dan Perbankan Islam Universitas Muhammadiyah Yogyakarta. Skripsi Fakultas Ekonomi, Universitas Muhammadiyah Yogyakarta, Yogyakarta 2016, 108

${ }^{23}$ Wawancara pada tanggal 5 Mei 2017

24 Wawancara pada tanggal 6 Juli 2017
} 
ANOVAa

\begin{tabular}{|ll|r|r|r|r|r|}
\hline Model & & Sum of Squares & \multicolumn{1}{|c|}{ df } & Mean Square & F & Sig. \\
\hline \multirow{2}{*}{1} & Regression & 345,887 & 3 & 115,296 & 39,728 &, $000^{\mathrm{b}}$ \\
& Residual & 319,236 & 110 & 2,902 & & \\
& Total & 665,123 & 113 & & & \\
\hline
\end{tabular}

a. Dependent Variable: Minat menjadi Nasabah Bank Syariah

b. Predictors: (Constant), Persepsi Nilai syari'ah, Persepsi Kualitas Pelayanan, Persepsi Kualitas Produk

Nilai F pada tabel Distribusi F dicari dengan memperhatikan banyaknya variabel bebas sebagai pembilang dan $[\mathrm{n}-(\mathrm{k}+1)] ; 114-(3+1)=110$ sebagai penyebut. Dalam tabel, dicari angka yang mendekati 110, yaitu 120 sehingga terbaca nilai- $\mathrm{F}_{\text {tabel }}$ pada $\alpha=5 \%(0,05)$ adalah 2,68. Dilihat dari hasil nilai $\mathrm{F}$ pada

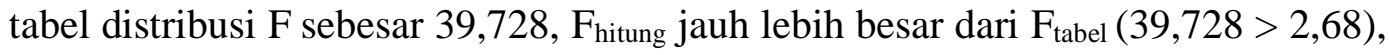
dengan tingkat signifikansi $0,000<0,05$. Artinya, persepsi kualitas produk, persepsi kualitas pelayanan, dan persepsi nilai syariah secara bersama-sama berpengaruh signifikan terhadap minat menjadi nasabah bank syariah.

\section{Pengujian Koefisien Determinasi}

Koefisien determinasi $\left(\mathrm{R}^{2}\right)$ menjelaskan proposi variasi dalam variabel terikat (Y) yang dijelaskan oleh variabel bebas (lebih dari satu variabel : $\mathrm{X}_{\mathrm{i}}$; i =1,2,3) secara bersama-sama. Hasil uji koefisien determinasi dapat di lihat pada tabel di bawah ini:

Tabel 4. Hasil Uji Koefisien Determinasi

\begin{tabular}{|l|r|r|r|r|r|}
\hline Model & $\mathrm{R}$ & $\mathrm{R}$ Square & $\begin{array}{c}\text { Adjusted R } \\
\text { Square }\end{array}$ & $\begin{array}{c}\text { Std. Error of the } \\
\text { Estimate }\end{array}$ & Durbin-Watson \\
\hline 1 &, $721^{\mathrm{a}}$ &, 520 &, 507 & 1,70357 & 1,762 \\
\hline
\end{tabular}
a. Predictors: (Constant), Persepsi Nilai syari'ah, Persepsi Kualitas Pelayanan, Persepsi
Kualitas Produk
ib. Dependent Variable: Minat menjadi Nasabah Bank Syariah

Berdasarkan tabel di atas dapat dilihat nilai koefisien determinasi (Adjusted $R$ Square) sebesar 0,507 atau 50,7\%, maka persepsi kualitas produk, persepsi kualitas pelayanan, dan persepsi nilai syariah mempengaruhi minat menjadi nasabah Bank Syariah sebesar 50,7\% dan 49,3\% (100\% - 50,7\%) dipengaruhi oleh variabel lain di luar variabel yang dipilih. Artinya, Persepsi kualitas produk, persepsi kualitas pelayanan, dan persepsi nilai syariah mempengaruhi minat menjadi nasabah Bank Syariah sebesar 50,7\% dilihat nilai koefisien determinasi (Adjusted R Square) dan 49,3\% (100\% - 50,7\%) dipengaruhi oleh variabel lain di luar variabel yang dipilih. 


\section{Kesimpulan}

Berdasarkan penelitian yang telah dilakukan dan telah dilakukan pengujian menemukan bahwa persepsi mahasiswa ekonomi Islam tentang kualitas produk dan kualitas pelayanan berpengaruh secara positif dan signifikan sedangkan persepsi tentang nilai syariah berpengaruh secara positif dan tidak signifikan. Hal tersebut disebebkan karena kebutuhan dasar mahasiswa yaitu menerima transfer dan adanya tugas perkuliahan sehingga nilai syariah tidak berpengaruh secara signifikan. Persepsi mahasiswa ekonomi Islam tentang kualitas produk, kualitas pelyanan, dan nilai syariah memiliki pengaruh yang positif dan signifikan secara bersama-sama, hal ini terbukti dengan hasil nilai $\mathrm{F}$ pada tabel distribusi $\mathrm{F}$ sebesar 39,728, F Fitung jauh lebih besar dari $F_{\text {tabel }}(39,728>2,68)$, dengan tingkat signifikansi $0,000<0,05$. Artinya, persepsi kualitas produk, persepsi kualitas pelayanan, dan persepsi nilai syariah secara bersama-sama berpengaruh signifikan terhadap minat menjadi nasabah bank syariah. Persepsi kualitas produk, persepsi kualitas pelayanan, dan persepsi nilai syariah mempengaruhi minat menjadi nasabah Bank Syariah sebesar 50,7\% dilihat nilai koefisien determinasi (Adjusted $R$ Square) dan 49,3\% (100\% - 50,7\%) dipengaruhi oleh variabel lain di luar variabel yang dipilih.

\section{Daftar Pustaka}

Faisal. 2016. Faktor-faktor Yang Mempengaruhi Minat Mahasiswa Untuk Menjadi Nasabah di Bank Syariah: Studi Kasus Mahasiswa Ekonomi dan Perbankan Islam Universitas Muhammadiyah Yogyakarta. Skripsi Fakultas Ekonomi, Universitas Muhammadiyah Yogyakarta, Yogyakarta 2016.

Hasan, Ali. 2010. Marketing Bank Syariah Cara Jitu Meningkatkan Pertumbuhan Pasar Bank Syariah. cet. ke-1. Bogor: PT Ghalia Indonesia.

Istiqomah, Rahayu. Faktor-faktor Yang Mempengaruhi Keputusan Mahasiswa Perbankan Syariah STAIN SALATIGA Untuk Menjadi Nasabah DI Perbankan Syariah. Skripsi Perbankan Syariah, STAIN SALATIGA, Salatiga 2015.

Nisfiannoor, Muhammad. 2009. Pendekatan Statistik Modern Untuk Ilmu Sosial. Jakarta: Salemba Humanika.

Sujarweni, V. Wiratna. (2014). Metode Penelitian; Lengkap, Praktis, dan Mudah Dipahami. Yogyakarta: Pustakabarupress.

Sugiyono. 2015. Metode Penelitian Kuantitatif, Kualitatif, dan R\&D. Cet. ke-22. Bandung: Alfabeta.

Sudarsono, Ardiansan. 2016. Manajemen Pemasaran Jasa Perhotelan. Ed. 1. Cet. ke-1. Yogyakarta: Deepublish.

Sanusi, Anwar. 2011. Metodologi Penelitian Bisnis. Jakarta: Salemba Empat.

Umar, Husein. 1997. Riset Sumber Daya Manusia. Jakarta: Gramedia Pustaka Utama. 
Internet:

Departmen Riset SEF UGM. Pengetahuan Ekonomi Islam di Kalangan Mahasiswa dan Preferensi Terhadap Bank Syariah di Indonesia, diakses pada tanggal 20 Maret 2017 dari http://www.kompasiana.com/abdulkarimismail/bank-idolaku-tumbuh-danberkembanglah-di-kancah-dunia-kapitalis_54ff2bc1a33311b34550fc86.

Mars Indonesia. Kepemilikan Rekening di Bank Syariah, diakses pada tanggal 20 maret 2017 dari www.marsindonesia.com/newsletter/kepemilikan-rekeningdi-bank-syariah-meningkat. 